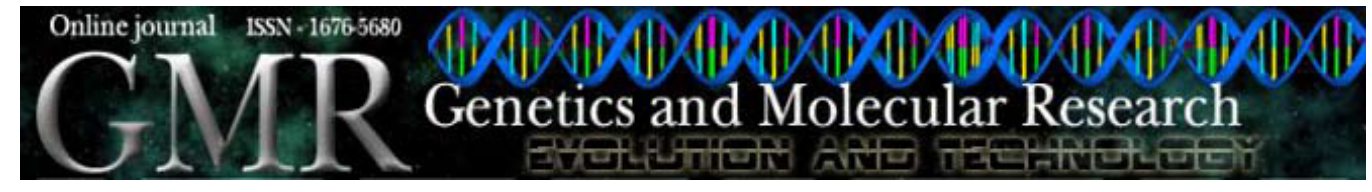

\title{
Modulatory effects of Duguetia furfuracea (A. St. Hil) Benth. and Hook. f. in Drosophila melanogaster somatic and germinative cells
}

\author{
${ }^{1}$ Departamento de Ciências Biológicas, \\ Universidade Estadual de Goiás, Goiânia, GO, Brasil \\ ${ }^{2}$ Departamento de Biologia Geral, \\ Universidade Federal de Goiás, Goiânia, GO, Brasil \\ ${ }^{3}$ Universidade de Brasília, Brasília, DF \\ ${ }^{4}$ Laboratório de Radiobiologia, \\ Universidade Federal de Goiás, Goiânia, GO, Brasil \\ Corresponding author: S. Carvalho \\ E-mail: salvadorcarvalho2005@yahoo.com.br
}

L.S. Coelho ${ }^{1}$, L.P. Felicio ${ }^{2}$, C.T. Miranda ${ }^{3}$, E.M. da Silva ${ }^{2}$, C.R. Vale ${ }^{2}$, D.C.S. Lima ${ }^{2}$, S.R. Duarte ${ }^{2}$, H.D. Ferreira ${ }^{2}$, L. Chen Chen ${ }^{4}$ and S. Carvalho ${ }^{2}$

Genet. Mol. Res. 10 (1): 75-85 (2011)

Received August 30, 2010

Accepted December 3, 2010

Published January 18, 2011

DOI 10.4238/vol10-1gmr983

\begin{abstract}
Mutagenic and antimutagenic activities of the medicinal plant Duguetia furfuracea were assessed using SMART/ wing and ring-X-loss tests. For the ring-X-loss test, 2- to 3-day-old Drosophila melanogaster ring-X-lineage males and virgin ywsn ${ }^{3}$ females received $D$. furfuracea infusion at doses of $0.085,0.042$, or $0.014 \mathrm{~g} / \mathrm{mL}$ for $24 \mathrm{~h}$. We found that $D$. furfuracea did not produce any mutagenic effects in $D$. melanogaster germinative cells. The somatic cells of $D$. melanogaster were analyzed using the SMART/ wing test involving three lineages - mwh, flr ${ }^{3}$, and ORR - and the same doses of $D$. furfuracea infusion employed in the ring-X-loss test, as well as $20 \mathrm{mM}$ urethane. The results of both standard (ST) and high bioactivation (HB) crosses showed absence of mutagenic activity of $D$. furfuracea. In contrast, in both ST and HB crosses, we
\end{abstract}


observed a modulatory effect of $D$. furfuracea against the genotoxic activity of urethane.

Key words: Antimutagenicity; Duguetia furfuracea; Genotoxicity; Mutagenicity

\section{INTRODUCTION}

The plant Duguetia furfuracea (A. St. Hil) Benth. and Hook. f. (Annonaceae) is frequently found in the Cerrado, a region covering mainly central Brazil, with populations composed of various individuals (Lorenzi, 2000). Tea made from the root has been used as a sedative, antirheumatic and for the treatment of renal and back pain. It has also been used against kidney disease. Screening of plant species in this family is of great importance since substances with cytotoxic, antiplasmodial, antiparasitic, pesticidal, antimicrobial, antifungal, antimalarial, antioxidant, and antitumor activities have been identified (Frana and Sufredini, 2000; Garcia et al., 2000; de Sousa et al., 2003).

Oxoaporphine alkaloids belong to the Annonaceae family and are known for their biological and pharmacological activities: cytotoxic, antiplatelet, antibacterial, and antifungal. Among these activities, the most representative in the Duguetia genus is cytotoxicity, which has been demonstrated in experiments using different strains of tumor cells. This is the case for the commonly isolated substance liriodenine (Silva et al., 2007). Liriodenine is a potent topoisomerase II inhibitor (Woo et al., 1999).

Studies on the chemical composition of $D$. furfuracea essential oil showed a high percentage of alkaloids, including monoterpenes and sesquiterpenes (Silva et al., 2007; Valter et al., 2008). Flavonoid glycosides are also found in this plant (Carollo et al., 2006).

Da Silva et al. (2009) showed the antitumoral, trypanocidal and antileishmanial activities of the extract and alkaloids isolated from D. furfuracea. Ethanolic extracts of D. furfuracea were tested for larvicidal activity against third-stage Aedes aegypti larvae and showed activity ( $>65 \%$ mortality) at $56.6,162.31,232.4,285.76$, and $384.37 \mu \mathrm{g} / \mathrm{mL}$ (Rodrigues et al., 2006).

In a phytochemical study of the plant Hornschuchia obliqua (Annonaceae), Fechine et al. (2002) reported the presence of the alkaloids roemerine, guadiscine, liriodenine, cleistopholine, and azanthraquinone, already described in the literature and found for the first time in this genus.

Silva et al. (2007) carried out biomonitored phytochemical studies of the extract obtained from the underground parts of $D$. furfuracea in a toxicity bioassay using brine shrimp (Artemia salina) and all extracts were active in the brine shrimp lethality bioassay.

Garcia et al. (2000) conducted a triage of extracts obtained from plants that belong to the families Combretaceae, Apocynaceae and Annonaceae in order to assess their possible anti-tumor activity and biomonitored isolates of active compounds against $A$. salina. Their results demonstrated that, among all the species tested, Annona coriacea (Annonaceae family) presented the highest toxicity. Tetrahydrofuranic acetogenine, possibly a gigantecin, isolated from A. coriacea leaves, was the most active compound, inhibiting human breast carcinoma cells.

Santos et al. (1996) isolated and determined the structure of a new acetogenine 
obtained from the ethanolic extract of $A$. crassiflora seeds, named crassiflorine. The same compound received three different names, crassiflorine, bullatanocine, and cherimoline-2, in Brazil, United States, and France, where it was isolated from different species of the Annona genus, A. crassiflora, A. bullata, and A. cherimolia, respectively (Cortes et al., 1993). This substance presented significant activity against human tumor cell lines in vitro when compared to adriamicine, a well-known antineoplastic agent (Santos et al., 1996). Crassiflorine anti-tumor activity has aroused great interest in $A$. crassiflora Mart. as a possible source of one natural antineoplastic agent (Santos and Boaventura, 1994).

Most acetogenines found in plants of the Annonaceae family have presented anti-tumor activity in vitro and in vivo against different neoplastic cell lines (de Sousa et al., 2003). A possible anti-tumor activity attributed to the acetogenines found in the plants of the Annonaceae family was experimentally demonstrated by the interruption of ATP production through the inhibition of the enzymes oxi-NADH ubiquinone-reductase (complex I) of the mitochondrial electron transport system (Pollo-Zafra et al., 1996) and ubiquinone-NADH oxidase enzyme, present in the plasma membrane of tumor cells (Morré et al., 1995).

Drugs employed in chemotherapy and radiotherapy, broadly employed in the treatment of cancer, can have undesirable side effects, such as inducing DNA damage in normal cells. It would be useful to investigate compounds that inhibit or reduce these effects. Therefore, it is necessary to find other drugs, and natural products are a good source. From 1983 to 1994 more than $60 \%$ of the approved anticancer drugs were found in natural products (Newman et al., 2003). The new drugs are also necessary in the treatment of trypanosomiasis and leishmaniasis, since current chemotherapy is still inadequate and causes many undesirable side effects (Da Silva et al., 2009).

$D$. furfuracea is widely used in folk medicine, and studies indicate that it has great potential as a trypanocidal and leishmanicidal agent, and possible latent activity against $A$. aegypti mosquito larvae, a vector of important diseases such as dengue and yellow fever. The widespread use of this plant makes it necessary to investigate its possible genotoxic, mutagenic and antimutagenic activity. The present study shows the possible effects of the medicinal plant $D$. furfuracea using the ring-X-loss test, which permits the detection of its possible genotoxic activity against Drosophila melanogaster since it shows the response of germinative cells to mutagenic compounds (Cunha et al., 1992), and the SMART/wing test, which assesses mutagenicity in somatic cells (Graf et al., 1984).

\section{MATERIAL AND METHODS}

The leaves of $D$. furfuracea used to prepare the infusions were collected in the Cerrado region of the municipality of Paraúna, in the State of Goiás. In the laboratory, all leaves were washed with distilled water and dried at $45^{\circ} \mathrm{C}$ for $30 \mathrm{~min}$. The dried leaves were used to prepare the infusion at the moment of the treatment of the adults (ring-X-loss test) and the third-instar larvae (SMART/wing) of D. melanogaster.

\section{Ring-X-loss test}

The ring-X-loss test has a short duration and permits the assessment of the muta- 
genic activity of compounds by inducing genic mutations and chromosome breaks in $D$. melanogaster germinative cells. Using the ring-X-loss test in a single phase of spermatogenesis may lead to false-negative results. However, the brood method, which consists of successively mating treated males with virgin females at intervals of 3, 2 and 2 days, results in treated gametes at different phases of spermatogenesis, permitting the separation of sexual cells that become progressively younger at the time of treatment, thus ensuring the efficacy of the results obtained (Zijlstra and Vogel, 1988).

In order to carry out the ring-X-loss test, 2- to 3-day-old $D$. melanogaster ring-X-lineage males and virgin ywsn ${ }^{3}$ females were used, whose genotypes are, respectively, C1 (2) yB/y+ YBS and $\mathrm{ywsn}^{3} / \mathrm{ywsn}^{3}$ (Lindsley and Grell, 1968; Lindsley and Zimm, 1992). For the experimental procedure, aliquots of $2.0 \mathrm{~mL}$ of different doses of $D$. furfuracea infusion $(0.085,0.042$, and $0.014 \mathrm{~g} / \mathrm{mL}$ ) were distributed in vials and 10 ring-X-lineage males, which had previously undergone a 4-h fast, were placed per vial and kept for $24 \mathrm{~h}$. After being exposed to the solutions for $24 \mathrm{~h}$, the males were mated to produce F1 offspring by removing them from the trip tubes and placing them into tubes containing banana-agar and virgin $\mathrm{ywsn}^{3}$ females where they were allowed to mate to produce Brood 1 offspring (metabolically inactive sperm cells). After 3 days the males were transferred to fresh tubes containing banana-agar and fresh $\mathrm{ywsn}^{3}$ virgin females where they mated and produced Brood 2 offspring (metabolically active mature cells). After a further 2 days the males were again transferred to fresh tubes containing banana-agar and fresh virgin ywsn ${ }^{3}$ females where they mated to produce Brood 3 offspring (immature sperm cells), the males being discarded after 2 days. In all cases the females were discarded after the eggs were collected and a thick layer of live fermenting yeast supplemented with sucrose was added to the tubes containing the larvae every 3 days. Urethane $(20 \mathrm{mM})$ was used as positive control and sterile distilled water as negative control. The experiment was performed in triplicate at $25^{\circ}$ $\pm 1^{\circ} \mathrm{C}$ and relative humidity of $60 \%$ (Lewis and Bacher, 1968). The individuals of this progeny were classified into phenotypic classes for statistical evaluation (Frei and Würgler, 1988).

The adult forms started to emerge on the 10th day. The F1 progeny were analyzed for 4 days by entomological microscopy technique. Assessment was made possible because the sexual chromosomes of both progenitors were marked with specific visible mutations, which enabled each chromosome (or segment) to be identified based on 1 of the 11 different possible F1 phenotype classes. The loss of one of the phenotypic markers could occur through several mechanisms, i.e., deletion of a section containing a given marker (1 or 2 breaks) or the loss or gain of an entire chromosome by non-disjunction.

The flies were divided into 11 classes, class $1-2=$ ring-X-loss and $3=$ complete ring$\mathrm{X}$-loss; 4 and $8=$ mosaicism; 6 and $7=$ partial loss of the Y-chromosome; 5, 9, 10, and $11=$ non-disjunction. The calculation of the frequency of complete loss of the ring-X-chromosome was obtained using the formula: $\%$ complete loss of the ring-X-chromosome $=$ class $3+$ class 4 divided by class $1+$ class $3+$ class $4+$ class $5+$ class 11 . The ring-X-loss test was performed according to the model proposed by Frei and Würgler (1988), and the results were classified as inconclusive, positive, weak positive, or negative.

\section{SMART/wing test}

Graf et al. (1984) developed a test system named somatic mutation and recombination test (SMART) based on two wing cell markers, multiple wing hair ( $m w h)$ and $f\left(a r e ~\left(f l r^{3}\right)\right.$, 
for the detection of mutagenic and recombinagenic activity of chemicals in D. melanogaster. Larvae trans-heterozygous for the mutations $m w h$ and $f r^{3}$ are exposed to the test compounds and induced mutations are detected as single spots on the wing blade of surviving adults, while induced recombination leads to $m w h$ and $f r^{3}$ twin spots and $m w h$ single spots. Two different crosses are currently used in the SMART: the standard (ST) cross $\left(\mathrm{flr}^{3} / \mathrm{TM}^{3} \mathrm{Bd}^{\mathrm{s}}\right.$ females mated with $m w h / m w h$ males) (Graf et al., 1989) and the high bioactivation (HB) cross (ORR; $\mathrm{flr}^{3} / \mathrm{TM}^{3} \mathrm{Bd}^{\mathrm{s}}$ females mated with $\mathrm{mwh} / \mathrm{mwh}$ males) (Graf and van Schaik, 1992). The latter cross is characterized by high sensitivity to promutagens and procarcinogens, since the ORR; $\mathrm{fl}^{3} / \mathrm{TM}^{3} \mathrm{Bd}^{\mathrm{s}}$ strains carry chromosomes 1 and 2 from a DDT-resistant Oregon $R(R)$ line (Dapkus and Merrell, 1977), which is characterized by an increased level of cytochrome p450 enzyme complex (Fragiorge et al., 2008).

In this study, for the SMART wing test in the ST and HB crosses we used three lines: a) multiple wing hair (mwh); b) $\mathrm{flr}^{3} \operatorname{In}(3 \mathrm{LR}) \mathrm{TM}^{3}$, ri pp sep I(3)89Aa bx34e and $\mathrm{Bd}^{\mathrm{s}}$; c) ORR;flr $3 / \mathrm{In}(3 \mathrm{LR}) \mathrm{TM}^{3}$, ri pp sep I(3)89Aa bx34e and $\mathrm{Bd}^{\mathrm{s}}$. The doses of $D$. furfuracea infusion, positive and negative controls, and culture media used to maintain $D$. melanogaster lines and in the assays were the same ones used in the ring-X-loss test. The oviposition medium was used to obtain the larvae and the instant culture medium (Formula 4-24 Carolina Biological Supply Company, Burlington, NC, USA) was employed for the development of the treated third-instar larvae (Graf et al., 1984). The experimental procedure for mutagenesis testing involved two types of crosses: 1) ST - mwh males mated with virgin $\mathrm{flr}^{3}$ females; 2) HB - mwh males mated with virgin ORR females. The flies were left to cross for 2 days. After that the males and females were transferred to vials containing the oviposition media and kept there for $8 \mathrm{~h}$. After $72 \pm 4 \mathrm{~h}$, third-instar larvae were collected by flotation in running water and distributed in vials containing $0.9 \mathrm{~g}$ synthetic media for D. melanogaster, $3 \mathrm{~mL}$ of the different doses of D. furfuracea infusion $(0.085,0.042$, and $0.014 \mathrm{~g} / \mathrm{mL}), 20 \mathrm{mM}$ urethane as positive control and sterile distilled water as negative control. The adult individuals were conserved in $70 \%$ ethanol. These assays were performed in triplicate at $25^{\circ} \pm 1{ }^{\circ} \mathrm{C}$ and approximately $60 \%$ relative humidity (Graf et al., 1984). The dorsal and ventral surfaces of D. melanogaster wings were analyzed with an optical microscope at a magnification of $400 \mathrm{X}$. The spots observed were classified according to their size, position in the wing, and type (single, twin) for evaluation and statistical analysis (Frei and Würgler, 1988, 1995).

\section{RESULTS AND DISCUSSION}

Table 1 presents the results of the ring-X-loss test using germinative cells of $D$. melanogaster. The progeny was classified into 11 phenotypic classes: class $1(\mathrm{Xp} / \mathrm{Xm})$; class 2 $\left(\mathrm{Xm} / \mathrm{y}+\mathrm{YB}^{\mathrm{s}}\right)$; class $3(\mathrm{Xm} / 0)$; class $4(\mathrm{Xm} / 0-\mathrm{Xm} / \mathrm{Xp})$; classes 6,7 , and $8\left(\mathrm{Xm} / \mathrm{y}+\mathrm{Y} ; \mathrm{Xm} / \mathrm{YB}^{\mathrm{s}}\right.$; $\mathrm{Xm} / \mathrm{y}+\mathrm{YB}^{\mathrm{s}}$-or $\left.\mathrm{Xm} / \mathrm{YB}^{\mathrm{s}}\right)$; classes 5, 9, 10, and $11\left(\mathrm{Xm} / \mathrm{Xp} / \mathrm{y}+\mathrm{YB}^{\mathrm{s}} ; \mathrm{Xm} / \mathrm{Xmy}+\mathrm{YB}^{\mathrm{s}} ; \mathrm{Xm} / \mathrm{Xmy}\right.$ $\mathrm{Xp} / \mathrm{o}$ ) of the Broods 1, 2, and 3.

Nunes and Carvalho (2003) evaluated the mutagenic potential of Cochlospermum regium in D. melanogaster germinative cells using the ring-X-loss test and reported a $1.13 \%$ loss of the ring-X-chromosome at the dose of $0.013 \mathrm{~g} / \mathrm{mL}$ in Brood 3. A similar result (1.15\%) was found in the present study for Brood 2 using $0.085 \mathrm{~g} / \mathrm{mL}$ D. furfuracea infusion and both studies presented negative results for mutagenesis. 


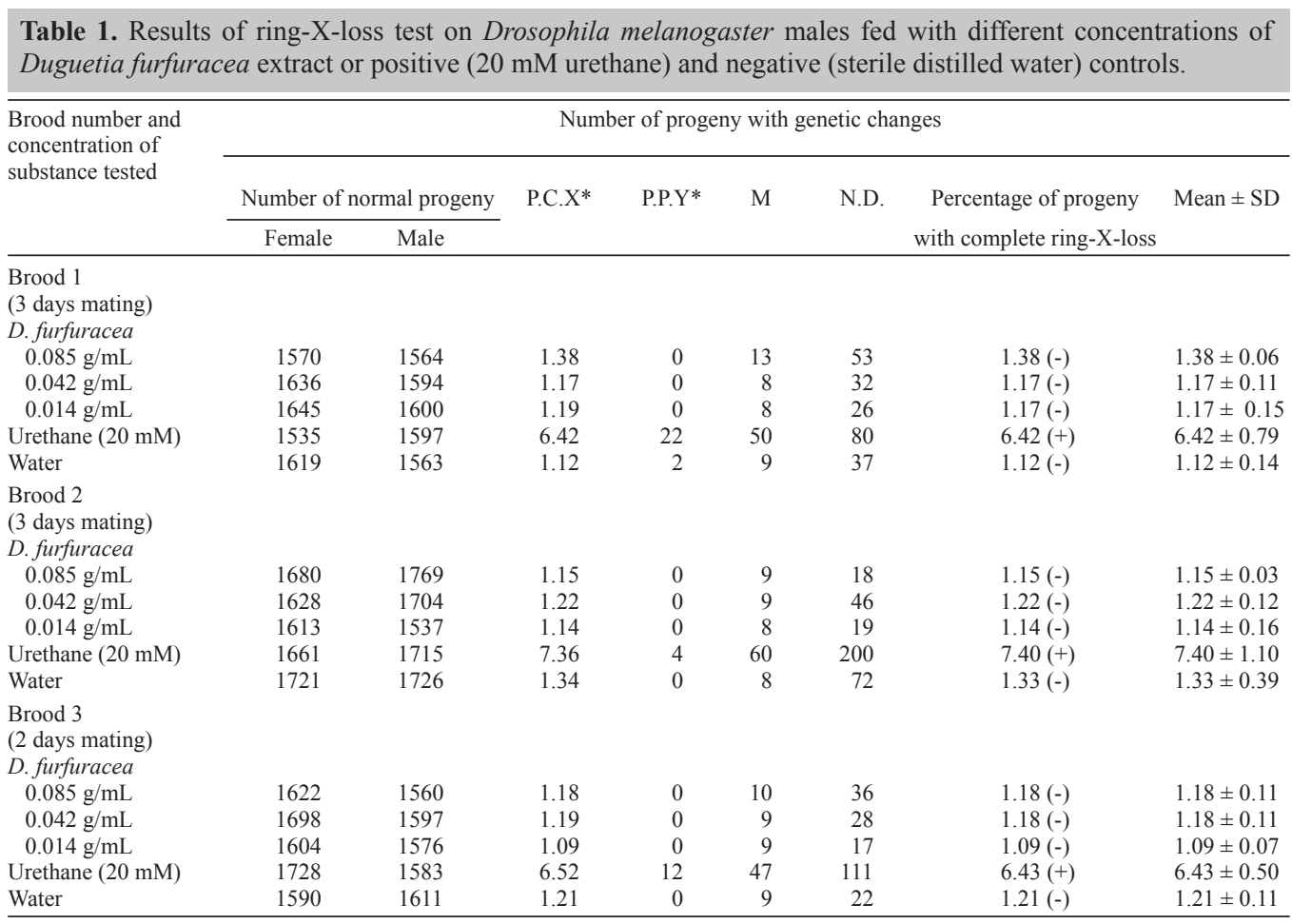

P.C.X = complete ring-X-loss; P.P.Y = partial loss of the Y-chromosome; $\mathrm{M}=$ mosaicism; N.D. = non-disjunction; $*=$ no statistically significant increases were detected between the negative control and the series treated with the infusion of $D$. furfuraceae ( $\chi^{2}$ for $2 \times 2$ contingency table).

The ring-X-loss test results using $D$. furfuracea infusion were also compared to those reported by de Sousa et al. (2003), who investigated the effect of Stryphnodendron adstringens in D. melanogaster germinative cells. Using $66 \%$ of the plant extract, the researchers observed a $1.37 \%$ loss of the ring-X-chromosome for Brood 3. In our experiments, we observed a $1.38 \%$ loss of the ring-X-chromosome for Brood 1 using the $0.085 \mathrm{~g} / \mathrm{mL}$ D. furfuracea infusion. Also, there was a similarity between the results for the negative control in both studies: a $1.82 \%$ loss of the ring-X-chromosome for Brood 2 using S. adstringens and a $1.21 \%$ loss of the ring-X-chromosome for Brood 3 using $D$. furfuracea. Furthermore, for the positive control (20 mM urethane), the results for the loss of the ring-X-chromosome were similar: $4.58 \%$ for Brood 1, 7.71\% for Brood 2, and 7.52\% for Brood 3 using S. adstringens; $6.42 \%$ for Brood 1, $7.40 \%$ for Brood 2, and $6.43 \%$ for Brood 3 using D. furfuracea. Thus, the results found in the present study are in accordance with those reported in the literature.

Table 2 presents the results for mutagenesis of D. furfuracea in D. melanogaster somatic cells, using the SMART/wing test, ST and HB crosses. The ST cross descendents treated with different doses of $D$. furfuracea infusion $(0.085,0.042$, and $0.014 \mathrm{~g} / \mathrm{mL})$ did not present a statistically significant increase $(\mathrm{P}>0.05)$ in the frequency of small single spots, large single spots, twin spots, or total spots compared to the negative control (sterile distilled water).

The HB cross descendents treated with $0.085,0.042$, and $0.014 \mathrm{~g} / \mathrm{mL}$ D. furfuracea 
infusion did not present a statistically significant increase $(\mathrm{P}>0.05)$ in the frequency of small single spots, large single spots, twin spots, or total spots compared to the negative control (sterile distilled water).

\begin{tabular}{|c|c|c|c|c|c|c|c|c|c|}
\hline \multirow{2}{*}{$\begin{array}{l}\text { Cross and AED } \\
\text { concentrations }\end{array}$} & \multirow{2}{*}{$\begin{array}{c}\text { No. of } \\
\text { Individuals }\end{array}$} & \multicolumn{8}{|c|}{ Frequency of mutant spots per individual (No. of spots) ${ }^{a}$} \\
\hline & & \multicolumn{2}{|c|}{$\begin{array}{c}\text { SSS } \\
(1-2 \text { cells })^{\mathrm{b}} \\
m=2\end{array}$} & \multicolumn{2}{|c|}{$\begin{array}{c}\text { LSS } \\
\begin{array}{c}(>2 \text { cells })^{\mathrm{b}} \\
m=5\end{array} \\
\end{array}$} & \multicolumn{2}{|c|}{$\begin{array}{l}\text { TWS } \\
m=5\end{array}$} & \multicolumn{2}{|c|}{$\begin{array}{l}\text { TOS } \\
m=2\end{array}$} \\
\hline $\begin{array}{l}\text { ST } \\
\text { Negative control } \\
\text { Urethane ( } 20 \mathrm{mM})\end{array}$ & 60 & 0.06 & (4) & 0.08 & (5) & 0.06 & (4) & 0.21 & (13) \\
\hline $\begin{array}{l}\text { D. furfuracea } \\
0.085 \mathrm{~g} / \mathrm{mL} \\
0.042 \mathrm{~g} / \mathrm{mL} \\
0.014 \mathrm{~g} / \mathrm{mL}\end{array}$ & $\begin{array}{l}60 \\
60 \\
60 \\
60\end{array}$ & $\begin{array}{l}0.31 \\
0.03 \\
0.03 \\
0.03\end{array}$ & $\begin{array}{l}(19)+ \\
(2)- \\
(2)- \\
(2)-\end{array}$ & $\begin{array}{l}0.76 \\
0.03 \\
0.05 \\
0.05\end{array}$ & $\begin{array}{l}(46)+ \\
(2)- \\
(3)- \\
(3)-\end{array}$ & $\begin{array}{l}0.76 \\
0.03 \\
0.03 \\
0.03\end{array}$ & $\begin{array}{l}(46)+ \\
(2)- \\
(2)- \\
(2)-\end{array}$ & $\begin{array}{l}1.76 \\
0.10 \\
0.11 \\
0.11\end{array}$ & $\begin{array}{r}(106) f^{+} \\
(6)- \\
(7)- \\
(7)-\end{array}$ \\
\hline $\begin{array}{l}\text { HB } \\
\text { Negative control } \\
\text { Urethane }(20 \mathrm{mM})\end{array}$ & 60 & 0.13 & $(8)$ & 0.06 & (4) & 0.08 & (5) & 0.28 & (17) \\
\hline $\begin{array}{l}\text { D. furfuracea } \\
0.085 \mathrm{~g} / \mathrm{mL} \\
0.042 \mathrm{~g} / \mathrm{mL} \\
0.014 \mathrm{~g} / \mathrm{mL}\end{array}$ & $\begin{array}{l}60 \\
60 \\
60 \\
60\end{array}$ & $\begin{array}{l}0.50 \\
0.06 \\
0.05 \\
0.06\end{array}$ & $\begin{array}{l}(30)+ \\
(4)- \\
(3)- \\
(4) \text { - }\end{array}$ & $\begin{array}{l}0.80 \\
0.03 \\
0.03 \\
0.03\end{array}$ & $\begin{array}{l}(48)+ \\
(2)- \\
(2)- \\
(2)-\end{array}$ & $\begin{array}{l}0.76 \\
0.03 \\
0.05 \\
0.03\end{array}$ & $\begin{array}{l}(46)+ \\
(2)- \\
(3)- \\
(2)-\end{array}$ & $\begin{array}{l}1.33 \\
0.13 \\
0.13 \\
0.13\end{array}$ & $\begin{array}{r}(124) \mathrm{f}^{+} \\
(8)- \\
(8)- \\
(98)-\end{array}$ \\
\hline
\end{tabular}

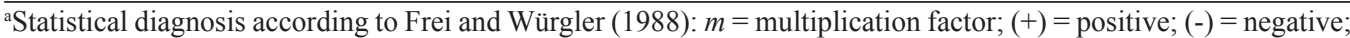
$\mathrm{f}=$ weakly positive. Significance level: $\alpha=\beta=0.05$. ${ }^{b}$ Including rare single spot $f l{ }^{3}$. SSS $=$ small single spots; LSS $=$ large single spots; TWS $=$ twin spots; TOS $=$ total spots. Negative control $=$ sterile distilled water.

Table 3 presents the results for antimutagenesis of D. furfuracea in D. melanogaster somatic cells, using the SMART/wing test, $\mathrm{ST}$ and HB crosses.

The results of ST cross repetition 1 using $0.085 \mathrm{~g} / \mathrm{mL}$ D. furfuracea infusion $+20 \mathrm{mM}$ urethane and $0.042 \mathrm{~g} / \mathrm{mL}$ D. furfuracea infusion $+20 \mathrm{mM}$ urethane showed a statistically significant increase $(\mathrm{P}>0.05)$ in the frequency of large single spots and twin spots compared to the positive control and a statistically significant decrease $(\mathrm{P}<0.05)$ in the frequency of small single spots and total spots compared to the positive control.

The results of the ST cross using $0.085 \mathrm{~g} / \mathrm{mL}$ D. furfuracea infusion $+20 \mathrm{mM}$ urethane presented a statistically significant decrease $(\mathrm{P}<0.05)$ in the frequency of small single spots and total spots compared to the positive control (20 mM urethane). The same situation was observed for $0.042 \mathrm{~g} / \mathrm{mL}$ D. furfuracea infusion $+20 \mathrm{mM}$ urethane and for $0.014 \mathrm{~g} / \mathrm{mL} \mathrm{D}$. furfuracea infusion $+20 \mathrm{mM}$ urethane.

The results of the HB cross using the same doses of D. furfuracea infusion $+20 \mathrm{mM}$ urethane presented a statistically significant decrease $(\mathrm{P}<0.05)$ in the frequency of small single spots, large single spots and total spots.

de Sousa et al. (2003) studied the possible genotoxic activity of the phytotherapic $S$. adstringens (Mart) in D. melanogaster somatic cells using the SMART/wing test. They concluded that there was a statistically significant increase in results, and can be correlated to the present study since it presented similar characteristics. The authors found the frequency of 0.41 (23) and 0.37 (20), respectively, for total spots in the negative control of the ST and HB crosses using S. ad- 


\begin{tabular}{|c|c|c|c|c|c|c|c|c|c|}
\hline \multirow{2}{*}{$\begin{array}{l}\text { Cross and AED + URE } \\
\text { concentrations }\end{array}$} & \multirow{2}{*}{$\begin{array}{c}\text { No. of } \\
\text { Individuals }\end{array}$} & \multicolumn{8}{|c|}{ Frequency of mutant spots per individual (No. of spots) ${ }^{\mathrm{a}}$} \\
\hline & & \multicolumn{2}{|c|}{$\begin{array}{c}\text { SSS } \\
\begin{array}{c}(1-2 \text { cells })^{b} \\
m=2\end{array}\end{array}$} & \multicolumn{2}{|c|}{$\begin{array}{c}\text { LSS } \\
\begin{array}{c}(>2 \text { cells })^{\mathrm{b}} \\
m=5\end{array}\end{array}$} & \multicolumn{2}{|c|}{$\begin{array}{l}\text { TWS } \\
m=5\end{array}$} & \multicolumn{2}{|c|}{$\begin{array}{c}\text { TOS } \\
m=2\end{array}$} \\
\hline \multicolumn{10}{|l|}{ ST } \\
\hline Negative control & 60 & 0.05 & (3) & 0.00 & $(0)$ & 0.00 & $(0)$ & 0.05 & (3) \\
\hline Urethane $(20 \mathrm{mM})$ & 60 & 3.70 & (222) & 0.22 & (13) & 0.01 & (6) & 4.01 & (241) \\
\hline \multicolumn{10}{|l|}{ D. furfuracea + urethane } \\
\hline $0.085 \mathrm{~g} / \mathrm{mL}+20 \mathrm{mM}$ & 60 & 0.28 & $(17) \downarrow$ & 0.06 & (4) & 0.01 & (1) & 0.36 & $(22) \downarrow$ \\
\hline $0.042 \mathrm{~g} / \mathrm{mL}+20 \mathrm{mM}$ & 60 & 0.30 & $(18) \downarrow$ & 0.11 & (7) & 0.03 & (2) & 0.45 & $(27) \downarrow$ \\
\hline $0.014 \mathrm{~g} / \mathrm{mL}+20 \mathrm{mM}$ & 60 & 0.15 & $(9) \downarrow$ & 0.10 & (6) & 0.01 & (1) & 0.26 & $(16) \downarrow$ \\
\hline \multicolumn{10}{|l|}{$\mathrm{HB}$} \\
\hline Negative control & 60 & 0.08 & (5) & 0.00 & $(0)$ & 0.00 & $(0)$ & 0.08 & $(5)$ \\
\hline Urethane $(20 \mathrm{mM})$ & 60 & 5.15 & $(309)$ & 0.73 & (44) & 0.15 & (9) & 6.03 & $(362)$ \\
\hline \multicolumn{10}{|l|}{ D. furfuracea + urethane } \\
\hline $0.085 \mathrm{~g} / \mathrm{mL}+20 \mathrm{mM}$ & 60 & 0.45 & $(27) \downarrow$ & 0.08 & $(5) \downarrow$ & 0.05 & (3) & 0.58 & $(35) \downarrow$ \\
\hline $0.042 \mathrm{~g} / \mathrm{mL}+20 \mathrm{mM}$ & 60 & 0.33 & $(20) \downarrow$ & 0.06 & (4) $\downarrow$ & 0.03 & (2) & 0.43 & $(26) \downarrow$ \\
\hline $0.014 \mathrm{~g} / \mathrm{mL}+20 \mathrm{mM}$ & 60 & 0.30 & $(18) \downarrow$ & 0.10 & $(6) \downarrow$ & 0.00 & $(0)$ & 0.40 & $(24) \downarrow$ \\
\hline
\end{tabular}

astatistical diagnosis according to Frei and Würgler (1995): $\downarrow=$ frequency reduction of mutant spots; $m=$ multiplication factor ( $\chi^{2}$ test, two-tailed, to compare proportions). ' Including rare single spot $f r^{3}$. Significance level: $\alpha=\beta=0.05$. $\mathrm{SSS}=$ small single spots; LSS $=$ large single spots; TWS $=$ twin spots; TOS $=$ total spots. Negative control $=$ sterile distilled water.

stringens, whereas in our research using D. furfuracea these values were 0.21 (13) and 0.28 (17), respectively. Using $100 \% S$. adstringens, they observed the frequency of 0.18 (11) for induced spots in the ST cross, while with 0.085 and $0.042 \mathrm{~g} / \mathrm{mL}$ D. furfuracea infusions we found 0.11 (7). In the HB cross, using 66,75 , and $100 \% S$. adstringens the authors observed the frequencies of 0.30 (18), 0.42 (25), and 0.42 (25), respectively, for total induced spots, and in our research, using $0.085,0.042$, and $0.014 \mathrm{~g} / \mathrm{mL}$ D. furfuracea infusion, we found the frequency of $0.13(08)$ in the $\mathrm{HB}$ cross. Thus, there was evidence of absence of genotoxic effects for both plants.

Silva (1998) studied the mutagenesis and antimutagenesis of $D$. furfuracea in mice using the micronucleus technique (MN). The animals were treated with 100,200 , and $300 \mathrm{mg} / \mathrm{kg}$ leaf extract and sacrificed after 24 and $48 \mathrm{~h}$. The frequencies of MN/2000 cells were not significant when compared to the negative control, indicating an absence of mutagenic activity, corroborating the results of the present study, using D. melanogaster somatic and germinative cells. Nevertheless, they reported significant antimutagenesis results, presenting modulating effects on the damage caused by mitomycin $\mathrm{C}$ applied together with the phytotherapic. The authors observed the frequency of $21.2 \mathrm{MN} / 2000$ cells, $24 \mathrm{~h}$ after the treatment with $300 \mathrm{mg} / \mathrm{kg}$ D. furfuracea leaf extract, while the positive control presented $35.6 \mathrm{MN} / 2000$ cells, whereas after $48 \mathrm{~h}$ the positive control showed $9.6 \mathrm{MN} / 2000$ cells falling to $5.8 \mathrm{MN} / 2000$ cells. These results are in accordance with those observed in the present study, which also showed the modulatory effect of $D$. furfuracea infusion on the damage caused by urethane.

Mendanha et al. (2010) observed the antigenotoxic activity of the aqueous extract of Byrsonima verbascifolia using the SMART/wing test/wing. This medicinal plant has chemicals that are also present in D. furfuracea, such as flavonoids and terpenes, corroborating the results found in this study. 
Passos et al. (2010) have observed a protective effect of the medicinal plant Palicourea coriacea against damage induced by doxorubicin, using the SMART/wing. The main constituents of its leaves are alkaloids, triterpene and tannins.

Vilar et al. (2009) found that all doses of Ginkgo biloba extracts co-administered with mitomycin or cyclophosphamide to mice $(50,100$ and $200 \mathrm{mg} / \mathrm{kg}$ ) were significantly ( $\mathrm{P}<$ 0.05 ) effective, reducing the frequency of $\mathrm{MN}$, suggesting that $G$. biloba possesses both direct and indirect antimutagenic potential. This plant has chemical compounds, such as flavonoids and terpenoids, found in D. furfuracea.

Toledo et al. (2006) studied the possible abortive and toxic effects of D. furfuracea aqueous extract in pregnant rats (Rattus novergicus). Those researchers observed that the uterus of most treated rats presented cysts, which proves blastocyst implantation but without fetal development. The total number of corpus luteum of the treatment animals presented a significant decrease compared to the control group, therefore, showing the embryotoxicity of $D$. furfuracea. Nonetheless, in the present research, we detected an absence of mutagenic activity of $D$. furfuracea infusion in D. melanogaster somatic and germinative cells.

The presence of certain compounds, such as flavonoids and terpenoids, in D. furfuracea may protect cells against DNA damage (Silva et al., 2006), and they are likely to be responsible for the modulatory effect of this phytotherapeutic agent and absence of genotoxicity and mutagenicity. Nonetheless, further experiments using other models should be carried out to confirm these results, to elucidate the mechanisms used to modulate genotoxic effects, and to determine the ideal conditions to use D. furfuracea extracts without risks to human health.

This medicinal plant is a desmutagenic agent that, when combined with urethane, can block the interaction of fly DNA-urethane.

\section{CONCLUSION}

Following the procedures herein described, we conclude that the phytotherapic $D$. furfuracea did not present genotoxic effects in D. melanogaster germinative cells considering the loss of the ring-X-chromosome, partial loss of the Y-chromosome, mosaicism, and non-disjunction, and that $D$. furfuracea did not induce mutations and recombinations in the somatic cells of $D$. melanogaster, in ST and HB cross descendents. It did, however, present a protective effect against damage induced by urethane in both ST and HB crosses.

\section{ACKNOWLEDGMENTS}

We would like to extend our thanks to the Departamento de Ciência Biológicas, Universidade do Estado de Mato Grosso, Departamento de Biología Celular y Anatomía, Universidad de Léon, and Universidade Federal de Goiás for use of the facilities and technical support, and the Post-Graduate Program in Cellular and Molecular Biology and ICB/UFG.

\section{REFERENCES}

Carollo CA, Hellmann-Carollo AR, Siqueira JM and Albuquerque S (2006). Alkaloids and a flavonoid from aerial parts (leaves and twigs) of Duguetia furfuracea - Annonaceae. J. Chil. Chem. Soc. 51: 837-841.

Cortes D, Mynt SH, Dupont B and Davoust D (1993). Bioactive acetogenins from seeds of Annona cherimolia. Phytochemical 32: 1475-1482. 
Cunha KS, Santos JH, Correa MJF and Lehmann M (1992). Avaliação do potencial mutagênico do ácido tânico em células germinais de Drosophila melanogaster. Rev. Bras. Genet. 15: 69.

Da Silva DB, Tulli EC, Militao GC, Costa-Lotufo LV, et al. (2009). The antitumoral, trypanocidal and antileishmanial activities of extract and alkaloids isolated from Duguetia furfuracea. Phytomedicine 16: 1059-1063.

Dapkus D and Merrell DJ (1977). Chromosomal analysis of DDT-resistance in a long-term selected population of Drosophila melanogaster. Genetics 87: 685-697.

de Sousa NC, de Carvalho S, Spano MA and Graf U (2003). Absence of genotoxicity of a phytotherapeutic extract from Stryphnodendron adstringens (Mart.) Coville in somatic and germ cells of Drosophila melanogaster. Environ. Mol. Mutagen. 41: 293-299.

Fechine IM, Cunha EVL, Filho JMB, Silva MS, et al. (2002). Alcalóides isolados de Hornschuchia obliqua (Annonaceae). XVIII Simpósio de Plantas Medicinais do Brasil, Recife.

Fragiorge EJ, Rezende AA, Graf U and Spano MA (2008). Comparative genotoxicity evaluation of imidazolinone herbicides in somatic cells of Drosophila melanogaster. Food Chem. Toxicol. 46: 393-401.

Frana AS and Sufredini IB (2000). Determinação da Atividade Citotóxica em Artêmia de Extratos de Anonaceae. In: XVI Simpósio de Plantas Medicinais do Brasil. Recife, 175.

Frei H and Würgler FE (1988). Statistical methods to decide whether mutagenicity test data from Drosophila assays indicate a positive, negative, or inconclusive result. Mutat. Res. 203: 297-308.

Frei H and Würgler FE (1995). Optimal experimental design and sample size for the statistical evaluation of data from somatic mutation and recombination tests (SMART) in Drosophila. Mutat. Res. 334: 247-258.

Garcia EF, Oliveira AB, Lopez MT and Braga FC (2000). Triagem de Extratos Vegetais para Atividade antitumoral e isolamento biomonitorado de substâncias ativas de Annona coriacea (Annonaceae). XVI Simpósio de Plantas Medicinais do Brasil, Recife, 186

Graf U and van Schaik N (1992). Improved high bioactivation cross for the wing somatic mutation and recombination test in Drosophila melanogaster. Mutat. Res. 271: 59-67.

Graf U, Würgler FE, Katz AJ, Frei H, et al. (1984). Somatic mutation and recombination test in Drosophila melanogaster. Environ. Mol. Mutagen. 6: 153-188.

Graf U, Frei H, Kagi A, Katz AJ, et al. (1989). Thirty compounds tested in the Drosophila wing spot test. Mutat. Res. 222: 359-373.

Lewis EB and Bacher F (1968). Methods of feeding ethyl methane sulfonate (EMS) to Drosophila males. Dros. Inf. Serv. $43: 193$.

Lindsley DL and Grell EH (1968). Genetic variation of Drosophila melanogaster. Carnegie Inst. Washington Publ. 627: 472.

Lindsley DL and Zimm GG (1992). The Genome of Drosophila melanogaster. New York Academic Press, New York, 481-483.

Lorenzi H (2000). Plantas Daninhas do Brasil - Terrestres, Aquáticas, Parasitas e Tóxicas. $3^{\text {a }}$ ed. Instituto Plantarum, Nova Odessa, 608.

Mendanha DM, Ferreira HD, Felicio LP, Silva EM, et al. (2010). Modulatory effect of Byrsonima verbascifolia (Malpighiaceae) against damage induced by doxorubicin in somatic cells of Drosophila melanogaster. Genet. Mol. Res. 9: 69-77.

Morré DJ, de Cabo R, Farley C, Oberlies NH, et al. (1995). Mode of action of bullatacin, a potent antitumor acetogenin: inhibition of NADH oxidase activity of HeLa and HL-60, but not liver, plasma membranes. Life Sci. 56: 343-348.

Newman DJ, Cragg GM and Snader KM (2003). Natural products as sources of new drugs over the period 1981-2002. J. Nat. Prod. 66: 1022-1037.

Nunes WB and Carvalho S (2003). Evaluation of the mutagenic potential of Cochlospermum regium in Drosophila melanogaster male germ cells. Genet. Mol. Biol. 26: 545-549.

Passos DC, Ferreira HD, Vieira IL, Nunes WB, et al. (2010). Modulatory effect of Palicourea coriacea (Rubiaceae) against damage induced by doxorubicin in somatic cells of Drosophila melanogaster. Genet. Mol. Res. 9: 1153-1162.

Pollo-Zafra MC, González MC, Estornell E, Sahpaz S, et al. (1996). Acetogenins from Annonaceae, inhibitors of mitochondrial complex I. Phytochemistry 42: 253-271.

Rodrigues AM, De Paula JE, Degallier N, Molez JE, et al. (2006). Larvicidal activity of some Cerrado plant extracts against Aedes aegypti. J. Am. Mosq. Control Assoc. 22: 314-317.

Santos PL and Boaventura MDA (1994). Crassiflorina, uma acetogenina tetra-hidrofurância citotóxica de Annona crassiflora (araticum). Quím. Nova 17: 387-391.

Santos PL, Boaventura MDA, Sun NJ, Cassady MJ, et al. (1996). Araticulin, a bis-tetrahydrofuran polyketide from Annona crassiflora seeds. Elsevier Sci. 42: 705-707.

Silva SR (1998). Plantas do Cerrado Utilizadas pelas Comunidades da Região do Grande Sertão Veredas. Fundação PróNatureza, Brasília.

Silva CJ, Ferreira HD, Ferri PH, Nunes WB, et al. (2006). Ausência de atividade mutagênica de Guazuma ulmifolia Lamb. (mutamba) em células somáticas de Drosophila melanogaster. Rev. Biol. Neotrop. 3: 163-168.

Silva DB, Tulli ECO, Garcez WS, Nascimento EA, et al. (2007). Chemical constituents of the underground stem bark of 
Duguetia furfuracea (Annonaceae). J. Braz. Chem. S. 18: 1560-1565.

Toledo MRS, Peres MTLP, Vieira MC, Bazzano TSC, et al. (2006). Fitotoxicidade do extrato aquoso de Duguetia furfuraceae (St. Hill) B et H em ratas (Rattus norvegicus). Rev. Bras. Plant. Med. 8: 217-222.

Valter JL, Alencar KMC, Sartori ALB, Nascimento EAN, et al. (2008). Variação química no óleo essencial das folhas de seis indivíduos de Duguetia furfuracea (Annonaceae). Rev. Bras. Farmacogn. 18: 373-378.

Vilar JB, Leite KR and Chen CL (2009). Antimutagenicity protection of Ginkgo biloba extract (Egb 761) against mitomycin C and cyclophosphamide in mouse bone marrow. Genet. Mol. Res. 8: 328-333.

Woo SH, Sun NJ, Cassady JM and Snapka RM (1999). Topoisomerase II inhibition by aporphine alkaloids. Biochem. Pharmacol. 57: 1141-1145.

Zijlstra JA and Vogel EW (1988). The ratio of induced recessive lethals to ring-X loss has prognostic value in terms of functionality of chemical mutagens in Drosophila melanogaster. Mutat. Res. 201: 27-38. 